\title{
Determinants Influencing Tax Compliance: The Case of Vietnam*
}

\author{
Thi Thuy Dương NGUYEN*, Thi My Linh PHAM**, Thanh Tam LE ${ }^{* * *}$ \\ Thi Hoai Linh TRUONG****, Manh Dung TRAN ${ }^{* * * * *}$
}

Received: December 1, 2019 Revised: December 11, 2019 Accepted: December 18, 2019

\begin{abstract}
The purpose of this paper is to ascertain the key factors affecting tax compliance among Vietnamese firms in Vietnam. We employ both qualitative and quantitative research methods. Qualitative research has been carried out through focus group discussions with ten chief accountants and tax officers. Quantitative research has been conducted through interviews with 200 firms (chief accountants or financial directors) in Vietnam. Analysis of the model includes the following stages: (i) Cronbach's test for reliability of the scale, (ii) exploratory factor analysis (EFA), (iii) confirmatory factor analysis (CFA), and (iv) structural equation model (SEM). The results of the research show that voluntary tax compliance is directly affected by the three factors of audit probability, corporate reputation and business ownership. The probability of audit and severity of sanctions have the strongest impact on tax compliance. Therefore, the tax authorities need to strengthen the inspection of tax declarations, tax payments and tax refunds of firms. The paper confirms that enforced tax compliance is directly affected by the three factors of audit probability, sanction severity and social norms. Voluntary compliance and compulsory compliance have an effect on tax compliance, though voluntary compliance has a more powerful impact.
\end{abstract}

Keywords: Voluntary Tax Compliance, Enforced Tax Compliance, Tax Compliance, Vietnamese Firms

JEL Classification Code: H20, H25, C83, G38.

\section{Introduction}

The self-assessment system is considered to be a modern mechanism of tax administration which is applied in many countries around the world. It is based on the voluntary compliance of tax payers and supports risk management techniques. Having been applied in Vietnam since 2004, this mechanism can be construed as having contributed to

*This research is funded by National Economics University, Hanoi, Vietnam.

*First Author and Corresponding Author, Associate Professor, School of Banking and Finance, National Economics University, Hanoi, Vietnam [Postal Address:_Room 914 - A1 Building, School of Banking and Finance, National Économics University, No. 207, Giai Phong Road, Hai Ba Trung District, Hanoi, 100000, Vietnam]

Tel: +84989308 846 Email: duongnt2013@gmail.com

${ }^{* *} \mathrm{PhD}$, Vietnam Trade Union University.

Email: mylinhlovely204@yahoo.com

***Associate Professor, National Economics University, Hanoi, Vietnam. Email: tamlt@neu.edu.vn

${ }^{* * * *} \mathrm{PhD}$, National Economics University, Hanoi, Vietnam. Email: trhoailinh3005@gmail.com

${ }_{* * \star * \star}$ Associate Professor, National Economics University, Hanoi, Vietnam. Email: manhdung@ktpt.edu.vn

() Copyright: Korean Distribution Science Association (KODISA)

This is an Open Access article distributed under the terms of the Creative Commons Attribution NonCommercial License (https://creativecommons.org/licenses/by-nc/4.0/) which permits unrestricted noncommercial use, distribution, and reproduction in any medium, provided the original work is properly cited. an increase in the self-responsibility of taxpayers, reduced management costs for tax authorities and an overall increase in the efficiency of tax administration. However, when taxpayers do not voluntarily comply with the law and tax authorities display weak management, the selfassessement system can cause a loss in tax revenues. Therefore, the tax management strategy of many countries is aimed at improving compliance among taxpayers.

Tax compliance studies have been implemented for more than 40 years. Many models and theories have been applied for the purpose of better understanding the factors affecting tax compliance. In general, tax compliance studies are based on three theoretical models: deterrence theories, economic and psychological models and behavioral models. The method of tax compliance research based on behavioral theory can be considered as a significant advance in tax compliance studies. It is argued that knowledge of compliance behavior goes far beyond deterrent factors and economic factors as described in previous theories. In order to study tax compliance more comprehensively, researchers have included in their research models new factors such as psychological, moral and social factors that influence tax compliance. 
Feld and Fray (2007) argued that a psychological tax contract goes beyond the traditional deterrence model and explains tax morale as a complicated interaction between tax payers and the government. Vogel (1974) stated that social norms, beliefs and a sense of fairness are also factors that have a strong impact on tax compliance. The theory of behavior as well as other psychological aspects such as morale, encouragement, and emotions between taxpayers and tax authorities are explored to understand compliance behavior and achieve better compliance.

Despite the growing prevalence of research on tax compliance, the findings from these studies have nonetheless been inconsistent. Although tax compliance has been studied by scholars for a long time, not many researchers have investigated the reputation factors that affect tax compliance. Previous tax compliance studies have mainly been conducted in developed countries having comprehensive infrastructure and a fairly stable system of tax laws. Studies of tax compliance in countries with transition economies like Vietnam are still limited.

The most important task facing tax administration agencies today is to identify the factors affecting tax compliance of taxpayers so that appropriate and effective management measures can be taken. To help with this effort, the paper will focus on: (i) a literature review of factors for tax compliance, (ii) a quantity model of tax compliance, and (iii) policy implications.

\section{Literature Review and Hypotheses}

To date, there have been two main research trends for approaching tax compliance issues: an economic approach, and a behavioral approach. When approaching from an economic standpoint, researchers apply economic theories. The behavioral approach applies concepts of psychology and sociology. The above approaches are summarized as follows:

\subsection{Tax Compliance Based on Economic Theories}

Allingham and Sandmo (1972) and Srinivasan (1973) are international researchers who have quantitatively studied the relationship between tax evasion and tax audits. It has been proved in many studies (Alm, Jackson, \& McKee, 1992b; Andreoni, Erard, \& Feinstein, 1998; Shanmugam, 2003; Dubin, 2007) that audit probability has a strong direct influence on the tax compliance of taxpayers. These studies show that in a self-assessment system, the possibility of tax audits plays an essential role in enhancing voluntary compliance, often having a positive impact on voluntary tax compliance. Research of Erich, Hoelzl, and Wahl (2008) pointed out that the possibility of tax audits has a positive impact on enforced tax compliance. Pommerehne and Weck-Hannemann (1996) concluded that enforced tax compliance will more successful if there is a higher probability of being tested.

Frey and Torgler (2007) asserted that as nobody likes paying taxes; the main reason for paying taxes on time is a fear of being punished. According to Swistak (2016) and Dubin, Graetz, and Wilde (1987), tax compliance behavior is affected by factors of detection and punishment. Erich et al. (2008) argued that the power of tax authorities has a strong impact on mandatory tax compliance.

\subsection{Tax Compliance Based on Social, Psychological and Behavioral Theories}

Much of the research on tax compliance is based on social and psychological theory (Elffers, Weigel, \& Hessing, 1987; Kristina, 2004; Tan, 1998). These studies suggest that the human factor is decisive for tax compliance behavior. The trust of taxpayers and tax morale has a significant effect on tax compliance. Experimental research carried out by Alm and Torgler (2006) and Cummings, MartinezVazquez, McKee, and Torgler (2009) showed that tax morale is an important factor in reducing tax evasion and increasing voluntary tax compliance. However, these studies do not show the relationship between tax morale and mandatory tax compliance. The empirical study of Liu (2014) also reveals that personal norms only affect voluntary tax compliance. They do not affect mandatory tax compliance.

Some empirical studies - including those of Traxler (2010) and Battiston and Gamba (2016) - show a close relationship between standard ethical factors and tax compliance. Alm, Jackson, and McKee (1992a), Jackson and Milliron (1986) and Eriksen and Fallan (1996) all believe that invisible concepts and pressures from society affect the decisions of taxpayers. Battiston and Gamba (2016) stated that social norms have a strong positive impact on the voluntary tax compliance. According to Erich et al. (2008), if taxpayers find that non-compliance is common behavior among people living around them, they too may choose not to comply with tax statutes. The empirical research of Liu (2014) asserts that social norms impact simultaneously on both voluntary tax compliance and mandatory tax compliance.

\subsection{Economic Theories with Social, Psychological and Behavioral Theories}


Recently undertaken research projects on tax compliance have incorporated not only economic, but also psychological and social factors. Molero and Pujol (2012) studied tax evasion behavior by analyzing the psychological expenses of taxpayers. Molero and Pujol (2012) developed the model of Allingham and Sandmo (1972) by adding some non-economic factors on tax compliance such as the "reputation" factor to show the relationship between tax compliance and tax consciousness. They suggested that taxpayers having good morals will not intend to evade taxes even if they will be able to obtain a clear economic benefit in doing so. Andreoni et al. (1998) and Kim (2003) showed that due to the fear of social stigma and decline in personal reputation, taxpayers tend to comply with tax systems. Alm et al. (1992b) argued that in order to encourage people to comply with taxes, a government compliance strategy based only on detection and punishment may well be a reasonable starting point, but far from comprehensive. Instead, it is necessary to have a multidimensional approach which emphasizes both enforcement in addition to positive rewards for better tax compliance and wise use of taxpayer funds.

\section{Research Methodology}

As of late, the Vietnamese tax authorities have been using many ways to help taxpayers attain a satisfactory understanding of policies and tax regulations, including informing of the public, mobilization and punishment. In fact, tax administration in Vietnam today is a combination of economic measures and psychological behavior. The main goal of tax administration is to encourage voluntary tax compliance among taxpayers. This is a common trend applied by many countries around the world.
Vietnam is a transitional economy. State-owned firms still exist in important areas such as oil and gas, telecommunications, and coal and minerals. These companies are often large-scale and contribute a significant amount of tax revenue. In-depth interviews conducted by the research team noted that if the taxpayers are private firms, their tax compliance attitudes may differ from those of state-owned firms. Therefore, the author decided to add business ownership to the model as a control variable.

H1a: Audit probability is positively correlated with voluntary tax compliance

H1b: Audit probability is positively correlated with enforced tax compliance..

H2: Sanction severity is positively correlated with enforced tax compliance.

H3a: Social norms are positively correlated with voluntary tax compliance.

H3b: Social norms are positively correlated with enforced tax compliance.

H4a: Corporate reputation is positively correlated with voluntary tax compliance.

H4b: Corporate reputation is positively correlated with enforced tax compliance.

H5: Personal norms are positively correlated with voluntary tax compliance.

H6a: Voluntary tax compliance is positively correlated with tax compliance.

H6b: Enforced tax compliance is positively correlated with tax compliance.

H7: Business ownership is positively correlated with voluntary tax compliance.

The model has nine scales with 30 observed variables, each measured on a five-level Likert scale varying from 1 (very unlikely) to 5 (very likely).

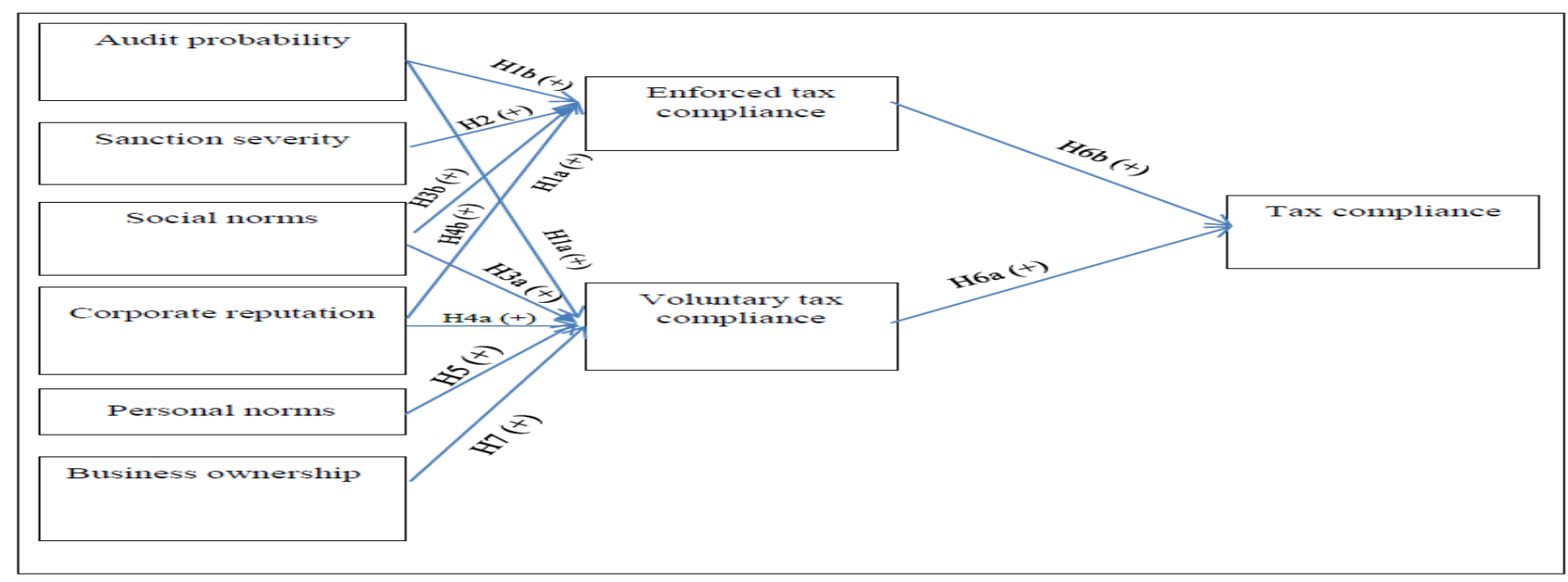

Figure 1: Model and hypotheses proposed 
Table 1: Summary of scales

\begin{tabular}{|c|c|c|c|}
\hline No & Scales & Symbol & Source \\
\hline $\mathbf{I}$ & Audit probability & KT & \multirow{4}{*}{ Bobek et al. (2007) } \\
\hline 1 & $\begin{array}{l}\text { How likely do you think it is that you will get audited if taxing authorities accept a } \\
\text { particular deduction in a case scenario? }\end{array}$ & KT1 & \\
\hline 2 & $\begin{array}{l}\text { If you are audited, how likely will it be that taxing authorities will disallow the } \\
\text { deduction? }\end{array}$ & KT2 & \\
\hline 3 & How likely do you think it is that your 2017 tax return will be audited? & KT3 & \\
\hline \multirow[t]{2}{*}{ II } & Sanction severity & $\mathbf{X P}$ & \multirow{6}{*}{ Wenzel (2004) } \\
\hline & $\begin{array}{l}\text { If the tax office detects tax evasion, how likely do you think possible the } \\
\text { following consequences? }\end{array}$ & & \\
\hline 1 & - $\quad$ paying the tax with a relatively small fine & XP1 & \\
\hline 2 & - $\quad$ paying a substantial fine & XP2 & \\
\hline 3 & being audited in more detail in coming years & $\mathrm{XP} 3$ & \\
\hline 4 & - $\quad$ criminal prosecution & XP4 & \\
\hline III & Social norms & $\mathbf{C M}$ & \multirow{6}{*}{$\begin{array}{l}\text { Bobek \& Hatfield } \\
(2003)\end{array}$} \\
\hline 1 & Most people I know would approve of me engaging in cheating behavior & CM1 & \\
\hline 2 & Most people I know will do anything to avoid paying tax & CM2 & \\
\hline 3 & I think it would be morally wrong to engage in cheating behavior with any amount & CM3 & \\
\hline 4 & If my friends knew, they would think it was wrong & CM4 & \\
\hline 5 & Most people who are important to me would think it was wrong & CM5 & \\
\hline IV & Personal norms & DDT & \multirow{4}{*}{ Wenzel (2005) } \\
\hline 1 & Do you think it is acceptable to underreport taxes? $*$ & DDT1 & \\
\hline 2 & $\begin{array}{l}\text { Do you think working for cash-in-hand payments without paying tax is a trivial } \\
\text { offence? } *\end{array}$ & DDT2 & \\
\hline 3 & Do you think you should honestly declare cash earnings on your tax returns? & DDT3 & \\
\hline $\mathbf{V}$ & Corporate reputation & DT & \multirow{6}{*}{$\begin{array}{l}\text { McDonald et al. } \\
(2010)\end{array}$} \\
\hline 1 & Our firm is viewed by customers as one that is successful & DT1 & \\
\hline 2 & We are seen by customers as being a very professional organization & DT2 & \\
\hline 3 & Customers view our firm as one that is stable & DT3 & \\
\hline 4 & Our firm's reputation with customers is highly regarded & DT4 & \\
\hline 5 & Our firm is viewed as well-established by customers & DT5 & \\
\hline \multirow[t]{2}{*}{ VI } & Voluntary tax compliance & TTTN & \multirow{7}{*}{ Erich \& Wahl (2010) } \\
\hline & When I pay my tax as required by the regulations, I do so: & & \\
\hline 1 & + Because to me, it's obvious that this is what you do & TTTN1 & \\
\hline 2 & + To support the state and other citizens & TTTN2 & \\
\hline 3 & + Because I like to contribute to the greater good & TTTN3 & \\
\hline 4 & + Because for me, it's the natural thing to do & TTTN4 & \\
\hline 5 & + Because I regard it as my duty as a citizen & TTTN5 & \\
\hline \multirow[t]{2}{*}{ VII } & Enforced tax compliance & TTBB & \multirow{6}{*}{ Erich \& Wahl (2010) } \\
\hline & When I pay my tax as required by regulations, I do so: & & \\
\hline 1 & + Because a great many tax audits are carried out & TTBB1 & \\
\hline 2 & + Because the Department of Revenue often carries out audits & TTBB2 & \\
\hline 3 & + Because I know I will be audited & TTBB3 & \\
\hline 4 & + Because the punishment for tax evasion is very severe & TTBB4 & \\
\hline VIII & $\begin{array}{l}\text { Business Ownership } \\
\text { Dummy variables receive value: } \\
\text { 1=State-owned firms occupying more than } 50 \% \text { of charter capital; } 0=\text { other cases }\end{array}$ & SH & \\
\hline
\end{tabular}

To measure tax compliance, the author uses a scale of (Sapiei, Kasipilai, \& Eze, 2014) developed from the scale of (Chan, Troutman, \& O’Bryan, 2000). The questionnaire developed for participants is set within the framework of a hypothetical scenario. Participants were asked to read two non-tax compliance scenarios and answer the following questions:

Scenario 1: Read the following and kindly indicate your opinion (by way of a tick) regarding the following scenario based on your experience:

Mr. A, a self-employed businessman is considering not disclosing a cash sale of VNĐ 550,000,000 as business income on his 2018 tax return. Legally, the cash receipts of VNĐ 550,000,000 should be included as business income. However, he is almost certain that the tax authorities will not audit him and would not know about the income if the amount is not disclosed.

(a) Taking into account all known and likely business circumstances, to what extent do you agree with Mr. A's possible action of not reporting the cash sale of VNĐ $550,000,000$ as business income? (TT01)

(b) Would he be likely to report only part of the VNĐ 
$550,000,000$ as business income? (TT02)

Scenario 2: Read the following and kindly indicate your opinion (by way of a tick) regarding the following scenario based on your experience:

Mr. B, a self-employed businessman, had incurred a cost of VNĐ 60,000,000 in repairing his personal van. In preparing his 2018 tax return, he is thinking about claiming the repair costs as if the van was used in his business. Legally, such a claim is not allowable, but he is almost certain that he will not be audited and that the tax authorities would not be able to detect the falsehood behind the deduction.

(a) Taking into account all known and likely business circumstances, to what extent do you agree with Mr. B's possible action of claiming VNĐ 60,000,000 as a business deduction? (TT03)

(b) Would he be likely to deduct only part of the VNĐ $60,000,000$ as a business deduction? (TT04)

Data used for this study were collected by interviews with 250 people throughout the period from October to December 2018 by employing convenient sampling and detailed questionnaires to test the model and hypothesis. Participants in the survey were the chief accountants or financial directors of Vietnamese firms. Among the 250 respondents, 50 people were deemed inappropriate, and thus rejected. Analysis of the model includes the following stages: (i) Cronbach's test for reliability of the scale, (ii) exploratory factor analysis (EFA), (iii) confirmatory factor analysis (CFA), and (iv) structural equation model (SEM).

\section{Results and Discussion}

Cronbach's alpha is used to measure scale reliability, while Exploratory Factor Analysis (EFA) is used to assess the convergent and discriminant validity of the scales. The results of Cronbach's alpha showed that all scales met reliability requirements. Specifically, all Cronbach's alpha coefficients are greater than 0.7 , with corrected item-total correlations greater than 0.5. All observed variables consistently measured specific concepts of factors, statistically and analytically significant. After that, the scales were evaluated by Exploratory Factor Analysis (EFA) to test unidimensionality of the scales to eliminate inappropriate measurement criteria.

After assessing the reliability of each scale by running EFA for each individual variable, the results showed that all initial items load on each research factor with eigenvalues greater than 1, all load factors greater than 0.4, and all KMO values greater than 0.5 . The Bartlett's test is significant at $p=0,000 \leq 5 \%$, which indicates that factor analysis is appropriate for further analysis of the research data. The results of EFA showed that all 20 items of five independent factors load on five factors with eigenvalues greater than 1, and $\mathrm{KMO}$ values $=0.758>0.5$. The Bartlett's test is significant at $p=0,000 \leq 5 \%$ for the variables measuring five factors: corporate reputation, sanction severity, social norms, personal norms and audit probability are all appropriate. The observed variables of factors are strongly correlated. After using matrix rotation, the results are shown as follows:

Table 2: Results after using matrix rotation

\begin{tabular}{|c|c|c|c|c|c|}
\hline \multicolumn{2}{|c|}{} & \multicolumn{5}{c|}{ Factors } \\
\cline { 2 - 6 } & $\mathbf{1}$ & $\mathbf{2}$ & $\mathbf{3}$ & $\mathbf{4}$ & $\mathbf{5}$ \\
\hline DT04 & .958 & & & & \\
\hline DT03 & .877 & & & & \\
\hline DT05 & .859 & & & & \\
\hline DT02 & .814 & & & & \\
\hline DT01 & .782 & & & & \\
\hline XP02 & & .877 & & & \\
\hline XP03 & & .826 & & & \\
\hline XP01 & & .795 & & & \\
\hline XP04 & & .785 & & & \\
\hline CM03 & & & .774 & & \\
\hline CM01 & & & .692 & & \\
\hline CM04 & & & .633 & & \\
\hline CM02 & & & .621 & & \\
\hline CM05 & & & .476 & & \\
\hline DDT02 & & & & .836 & \\
\hline DDT03 & & & & .829 & \\
\hline DDT01 & & & & .772 & \\
\hline KT02 & & & & & .792 \\
\hline KT01 & & & & & .753 \\
\hline KT03 & & & & & .664 \\
\hline
\end{tabular}

The above information details the observed variables' load on the specific research factors. Twenty observed variables of mandatory tax compliance and voluntary tax compliance scales achieved convergent and discriminant validity; those variables were then tested with CFA.

The results of CFA of the independent variables showed that both the TLI (measuring market fit) and CFI (Comparative Fit Index) showed good results, with values $>0.9$. In addition, the GFI (measuring goodness of fit) $=0.887$, improved but still not greater than 0.9 . However, the GFI with a value of 0.887 is still acceptable. Moreover, Dmin/Df $=1,678<3$ and RMSEA $=0.059<0.08$ are appropriate. The test results of model fit with actual data showed that Chi-square/df $<3$, TLI and CFI $>0.9$, while RMSEA $=0.059<0.08$; this is appropriate. However, GFI $=0.887$, approximately 0.9 , is not particularly good, but still acceptable for rounding the number up.

\subsection{Testing Research Model}

Chi-square/df $<3$, TLI and CFI $>0.9$, plus RMSEA $=$ $0.075<0.08$ are appropriate. However, GFI $=0.878$ is approximately 0.9 - as previously mentioned, not ideal, yet 
still adequate for rounding up the number. The results of regression estimation among observed variables in each latent variable are shown as follows:

Table 3: The results of regression estimation among observed variables in each latent variable

\begin{tabular}{|c|c|c|c|c|}
\hline Label & (Estimate) & (S.E) & (C.R) & P \\
\hline DT & .339 & .040 & 8.505 & $* * *$ \\
\hline XP & .409 & .056 & 7.346 & $* * *$ \\
\hline CM & .461 & .085 & 5.441 & $* * *$ \\
\hline DDT & .372 & .061 & 6.104 & $* * *$ \\
\hline KT & .068 & .037 & 1.808 & .071 \\
\hline
\end{tabular}

Note: $\mathrm{p}^{* * *}$ value corresponds to $\mathrm{p}<0.001$

Based on the results of the above table, most of the observed variables are statistically significant, corresponding to $\mathrm{p}<0.001$. The factor of probability of getting tax audits with a significance level of $p=0.071<10 \%$ is still acceptable.

\subsection{Testing Research Hypotheses}

Based on the results of testing model fit of the entire model and the results of regression analysis, all satisfied observed variables and latent variables are put into the model for hypothesis testing as shown in Figure 2. From the results of SEM of the entire model, the appropriateness of the testing model is relatively satisfied, specifically: Chisquare $/ \mathrm{df}=2.114<3, \mathrm{TLI}=0.906$ and $\mathrm{CFI}=0.923>0.9$, RMSEA $=0.075<0.08$, results which are appropriate. Only GFI $=0.878$, at approximately 0.9 , is not ideal, but is an acceptable value upon rounding up.

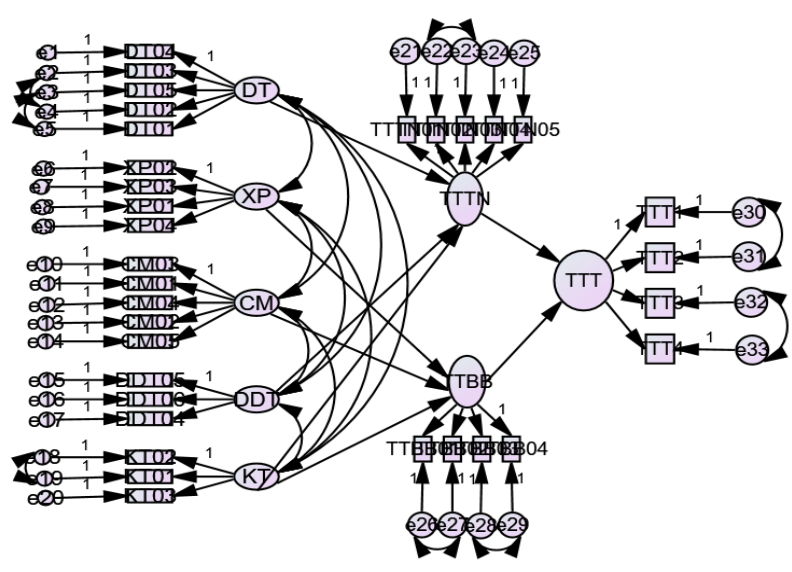

Figure 2: Model of hypothesis test

After obtaining the results of the model-fit test for the entire model, all satisfied observed variables and latent variables were put into the model of the hypothesis test.
From the results of SEM for the entire model, the appropriateness of the testing model is relatively satisfied. The results of the hypothesis test are shown in the tables "Regression Weights" and "Standardized Regression Weights".

The table of regression weights indicates that the hypotheses including the variable of audit probability (KT) have an impact on voluntary tax compliance (TTTN) and mandatory tax compliance (TTBB), the variable of sanction severity (XP) influences the mandatory tax compliance variable, the social norms $(\mathrm{CM})$ variable affects compulsory tax compliance, and finally the corporate reputation (DT) variable affects voluntary tax compliance at statistical significance $<10 \%$. Only the impact of personal norms (DDT) on voluntary tax compliance with a p-value $=0.700$ does not reach a level of statistical significance; as such, there is no evidence to find a correlation between personal norms and voluntary tax compliance in the scope of this research.

Table 4: Regression weights

\begin{tabular}{|ccl|l|l|l|c|}
\hline \multicolumn{3}{|c|}{ Label } & Estimate & S.E. & C.R. & P \\
\hline TTTN & $<---$ & DT & .235 & .135 & 1.742 & .081 \\
\hline TTTN & $<---$ & DDT & .059 & .154 & .385 & .700 \\
\hline TTTN & $<---$ & KT & 2.246 & .617 & 3.638 & $* * *$ \\
\hline TTBB & $<---$ & XP & .252 & .060 & 4.194 & $* * *$ \\
\hline TTBB & $<---$ & CM & .121 & .047 & 2.563 & .010 \\
\hline TTBB & $<---$ & KT & .493 & .187 & 2.633 & .008 \\
\hline TTT & $<---$ & TTTN & .262 & .077 & 3.409 & $* * *$ \\
\hline TTT & $<---$ & TTBB & .459 & .205 & 2.237 & .025 \\
\hline
\end{tabular}

Note: $\mathrm{p} * * *$ value corresponds to $\mathrm{p}<0.001$

The results of table of Standardized Regression Weights are displayed as follows:

Table 5: Standardized regression weights

\begin{tabular}{|lll|c|}
\hline & Label & & Estimate \\
\hline TTTN & $<---$ & DT & .238 \\
\hline TTTN & $<---$ & DDT & .057 \\
\hline TTTN & $<---$ & KT & .925 \\
\hline TTBB & $<---$ & XP & .710 \\
\hline TTBB & $<---$ & CM & .362 \\
\hline TTBB & $<---$ & KT & .575 \\
\hline TTT & $<---$ & TTTN & .684 \\
\hline TTT & $<---$ & TTBB & .423 \\
\hline
\end{tabular}

Table 5 shows the standardized regression weights, whereby all the coefficients are positive, indicating that the impact of the given hypotheses is positive. Thus, it is concluded that the hypotheses are supported, specifically:

H1a: Audit probability is positively correlated with voluntary tax compliance. 
H1b: Audit probability is positively correlated with enforced tax compliance.

H2: Sanction severity is positively correlated with enforced tax compliance.

H3b: Social norms are positively correlated with enforced tax compliance.

H4a: Corporate reputation is positively correlated with voluntary tax compliance.

H6a: Voluntary tax compliance is positively correlated with tax compliance.

H6b: Enforced tax compliance is positively correlated with tax compliance.

In continuing the analysis of the variable of business ownership by the SEM method, the results are as follows:

Chi-square $/ \mathrm{df}=1.994<3, \mathrm{TLI}=0.906$ and $\mathrm{CFI}=0.920$ $>0.9$, and RMSEA $=0.071<0.08$ are all appropriate. Only GFI $=0.815$, at approximately 0.9 , is not perfect, but nonetheless acceptable upon rounding up the number. The results of SEM of the entire model showed that the appropriateness of the testing model is relatively satisfied. The results of the hypothesis test are shown in the table "Standardized Regression Weights".

Table 6: Standardized regression weights

\begin{tabular}{|lll|l|l|l|l|}
\hline \multicolumn{3}{|c|}{ Label } & Estimate & S.E. & C.R. & P \\
\hline TTTN & $<---$ & DT & .227 & .120 & 1.885 & .059 \\
\hline TTTN & $<---$ & DDT & .069 & .136 & .504 & .614 \\
\hline TTTN & $<---$ & KT & 1.954 & .479 & 4.076 & $* * *$ \\
\hline TTBB & $<---$ & XP & .263 & .060 & 4.367 & $* * *$ \\
\hline TTBB & $<---$ & CM & .124 & .047 & 2.630 & .009 \\
\hline TTBB & $<---$ & KT & .467 & .163 & 2.866 & .004 \\
\hline TTBB & $<---$ & SH & -.028 & .066 & -.415 & .678 \\
\hline TTTN & $<---$ & SH & .366 & .097 & 3.768 & $* * *$ \\
\hline TTT & $<---$ & TTTN & .246 & .075 & 3.299 & $* * *$ \\
\hline TTT & $<---$ & TTBB & .411 & .189 & 2.180 & .029 \\
\hline TTT & $<---$ & SH & .162 & .078 & 2.075 & .038 \\
\hline
\end{tabular}

It is concluded from Table 6 that the ownership (SH) variable is related to voluntary tax compliance (TTTN) and tax compliance (TTT) with a statistical significance below $5 \%$. However, the ownership variable is not related to enforced tax compliance. The P-value $=0.678$ has not reached a statistically significant level, so there is no evidence to find a correlation between ownership and compulsory tax compliance in the scope of this research. In addition, correlations between ownership and voluntary tax compliance as well as ownership and tax compliance are positive, which indicates that firms with high state-ownership tend to have higher level of tax compliance. Thus, the test is consistent with the research hypothesis $\mathrm{H} 7$, "Ownership is positively correlated with voluntary tax compliance".

Based on the findings above, some discussion relating to the research topic as below: Firstly, voluntary tax compliance of Vietnamese firms is directly affected by three factors - audit probability, corporate reputation, and business ownership - and therefore hypotheses H1a, H4a and $\mathrm{H} 7$ are accepted. Enforced tax compliance of Vietnamese firms is directly affected by the three factors of audit probability, sanction severity and social norms; therefore, hypotheses $\mathrm{H} 1 \mathrm{~b}, \mathrm{H} 2$ and $\mathrm{Hb} 3$ are accepted. Voluntary compliance and compulsory compliance have an effect on tax compliance, but voluntary compliance has a more powerful impact. Audit probability strongly affects voluntary and compulsory tax compliance. Business ownership affects both voluntary compliance and tax compliance.

Secondly, the study does not provide evidence of the relationship between personal norms and voluntary tax compliance. This can be explained by the fact that, in Vietnam, tax compliance behavior has not been considered to be an ethical behavior, but rather a mandatory action. This is also explained by the Institutional Anomie Theory. Anomie is a sociological theory asserting that individuals make decisions based on social values, which can be contradictory if considered separately, but when put together, in balance with each other, creates behaviors which are considered "normal" by society. When one person holds an imbalanced set of values, decisions based on that set may produce deviant behavior such as daily offenses. Since there is a decline in the moral values of society, the possibility of unethical acts, such as tax evasion, may increase. According to the Institutional Anomie Theory, individualistic values will encourage manufacturing companies to make decisions based on economic benefits, rather than ethical or legal concerns, to achieve their objectives (Bame-Aldred, John, Kelly, \& Parboteeah, 2013). Therefore, in this study, the fact that personal norms do not affect tax compliance can be explained.

\section{Conclusions and Recommendations}

The research presents a new factor having a positive impact on voluntary tax compliance: the factor of business ownership. It is verified in the context of the transition economy in Vietnam. It has been proven that the corporate reputation or image of an enterprise has a positive impact on voluntary tax compliance. There are very few previous studies that distinguish between compulsory tax compliance and voluntary tax compliance. This study adds to the understanding of voluntary tax compliance and mandatory tax compliance.

Research results show that voluntary tax compliance has a more powerful impact on tax compliance than enforced compliance. The probability of audit and severity of sanctions have the strongest impact on tax compliance 
behavior, especially in the case of audit probability. Therefore, the tax authorities need to strengthen the inspection of tax declarations, tax payments and tax refunds of firms. Corporate reputation has an impact on voluntary tax compliance. Therefore, it is necessary to take measures to praise and encourage firms to comply with the law. The list of companies having high tax risks and tax debts should be publicized in the media. This also encourages other companies to be more active in voluntary tax compliance.

The social norm has an impact on compulsory compliance. However, the study has failed to find a link between personal norms - an important subjective factor that greatly influences tax compliance behavior according to many previous studies - and tax compliance of Vietnamese firms. It can be explained that the perception and consciousness of taxpayers in Vietnam are not particularly good. In order to raise social awareness about tax compliance, public information programs need to be promoted. Legal education should be included in educational programs at all levels of study in appropriate forms. However, the limitations of this research are: (i) the survey sample has just been limited to 200 observations; (ii) all factors affecting tax compliance behavior have not been fully evaluated in this study.

\section{References}

Allingham, M. G., \& Sandmo, A. (1972). Income tax evasion: A theoretical analysis. Journal of Public Economics, 1(3), 323-338.

Alm, J., \& Torgler, B. (2006). Culture differences and tax morale in the United States and in Europe. Journal of Economic Psychology, 27(2), 224-246.

Alm, J., Jackson, B., \& McKee, M. (1992a). Institutional uncertainty and taxpayer compliance. The American Economic Review, 82(4), 1018-1026.

Alm, J., Jackson, B., \& McKee, M. (1992b). Estimating the determinants of taxpayer compliance with experimental data. National Tax Journal, 107-114.

Andreoni, J., Erard, B., \& Feinstein, J. (1998). Tax compliance. Journal of Economic Literature, 36(2), 818860.

Bame-Aldred, C. W., John, B. C., Kelly, D. M., \& Parboteeah, K. P. (2013). National culture and firm-level tax evasion. Journal of Business Research, 66(3), 390396.

Battiston, P., \& Gamba, S. (2016). The impact of social pressure on tax compliance: A field experiment. International Review of Law and Economics, 46, 78-85.

Bobek, D. D., \& Hatfield, R. C. (2003). An investigation of the theory of planned behavior and the role of moral obligation in tax compliance. Behavioral Research in
Accounting, 15(1), 13-38.

Bobek, D. D., Roberts, R. W., \& Sweeney, J. T. (2007). The social norms of tax compliance: Evidence from Australia, Singapore, and the United States. Journal of Business Ethics, 74(1), 49-64.

Chan, C. W., Troutman, C. S., \& O’Bryan, D. (2000). An expanded model of taxpayer compliance: Empirical evidence from the United States and Hong Kong. Journal of International Accounting, Auditing and Taxation, 9(2), 83-103.

Cummings, R. G., Martinez-Vazquez, J., McKee, M., \& Torgler, B. (2009). Tax morale affects tax compliance: Evidence from surveys and an artefactual field experiment. Journal of Economic Behavior \& Organization, 70(3), 447-457.

Dubin, J. A. (2007). Criminal investigation enforcement activities and taxpayer noncompliance. Public Finance Review, 35(4), 500-529.

Dubin, J. A., Graetz, M. J., \& Wilde, L. L. (1987). Are we a nation of tax cheaters? New econometric evidence on tax compliance. The American Economic Review, 77(2), 240-245.

Elffers, H., Weigel, R. H., \& Hessing, D. J. (1987). The consequences of different strategies for measuring tax evasion behavior. Journal of Economic Psychology, 8(3), 311-337.

Erich, K., Hoelzl, E., \& Wahl, I. (2008). Enforced versus voluntary tax compliance: The "slippery slope" framework. Journal of Economic Psychology, 29(2), 210-225.

Erich, K., \& Wahl, I. (2010). Tax Compliance Inventory: TAX-I Voluntary tax compliance, enforced tax compliance, tax avoidance, and tax evasion. Journal of Economic Psychology, 31(3), 331-346.

Eriksen, K., \& Fallan, L. (1996). Tax knowledge and attitudes towards taxation; A report on a quasiexperiment. Journal of Economic Psychology, 17(3), 387402.

Feld, L. P., \& Frey, B. S. (2007). Tax compliance as the result of a psychological tax contract: The role of incentives and responsive regulation. Law \& Policy, 29(1), 102-120.

Frey, B. S., \& Torgler, B. (2007). Tax morale and conditional cooperation. Journal of Comparative Economics, 35(1), 136-159.

Jackson, B., \& Milliron, V. (1986). Tax compliance research: Findings, problems, and prospects. Journal of Accounting Literature, 5(1), 125-165.

Kim, Y. (2003). Income distribution and equilibrium multiplicity in a stigma-based model of tax evasion. Journal of Public Economics, 87(7), 1591-1616.

Kristina, M. (2004). The role of trust in nurturing compliance: A study of accused tax avoiders. Law and 
Human Behavior, 28 (2), 187-209.

McDonald, G., Svensson, G., \& Galbreath, J. (2010). How does corporate social responsibility benefit firms? Evidence from Australia. European Business Review, 22(4), 411-431.

Molero, J. C., \& Pujol, F. (2012). Walking inside the potential tax evader's mind: Tax morale does matter. Journal of Business Ethics, 105(2), 151-162.

Pommerehne, W. W., \& Weck-Hannemann, H. (1996). Tax rates, tax administration and income tax evasion in Switzerland. Public Choice, 88(1-2), 161-170.

LaFond, R. (2005). Is the accrual anomaly a global anomaly? (Working Paper No. 455-05). MIT Sloan School of Management. Retrieved from https://papers.ssrn.com/sol3/papers.cfm?abstract_id=782 726\&download=yes.

Sapiei, N. S., Kasipilai, J., \& Eze, U. C. (2014). Determinants of tax compliance behaviour of corporate taxpayers in Malaysia. eJournal of Tax Research, 12(2), 383-409.

Shanmugam, S. (2003). Managing self assessment-an appraisal. Tax Nasional, 1, 30-32.

Srinivasan, T. (1973). Tax evasion: A model. Journal of Public Economics, 2(4), 339-346.

Swistak, A. (2016). Tax penalties in SME tax compliance. Financial Theory and Practice, 40(1), 129-147.

Tan, L. M. (1998). Taxpayers perceptions of the fairness of the tax system-A preliminary study. New Zealand Journal of Taxation Law and Policy, 4, 59-71.

Traxler, C. (2010). Social norms and conditional cooperative taxpayers. European Journal of Political Economy, 26(1), 89-103.

Vogel, J. (1974). Taxation and public opinion in Sweden: an interpretation of recent survey data. National Tax Journal, 27, 499-513.

Wenzel, M. (2004). The social side of sanctions: personal and social norms as moderators of deterrence. Law and Human Behavior, 28(5), 547-567.

Wenzel, M. (2005). Motivation or rationalisation? Causal relations between ethics, norms and tax compliance. Journal of Economic Psychology, 26(4), 491-508. 